\title{
Experimentální laboratoř PLESS
}

\author{
Marek Vranka
}

Impulzem ke vzniku laboratoře PLESS byla především absence zázemí pro realizaci laboratorních experimentů na Filozofické fakultě Univerzity Karlovy. Marek Vranka a Štěpán Bahník, v té době sami doktorandi, se proto rozhodli takové zázemí vytvořit a usnadnit realizaci kvalitních a publikovatelných studií sobě i dalším studentům a studentkám se zájmem o psychologický výzkum.

Laboratoř od svého vzniku v roce 2013 poskytuje jak fyzický, tak online prostor pro realizaci výzkumů, databázi kontaktů pro nábor účastníků a know-how pro technické zabezpečení průběhu studií. Vytvořené zázemí využívají členové laboratoře ke svým výzkumům zejména v oblastech experimentální sociální psychologie, psychologie rozhodování či behaviorální ekonomie. O všech dosud provedených studiích, členech našeho týmu, a právě zkoumaných tématech se můžete více dočíst na stránkách www.pless.cz.

Členové laboratoře se rovněž aktivně zapojují do mnoha mezinárodních vědeckých spoluprací, replikačních studií a propagace praktik otevřené, transparentní a replikovatelné vědy. V minulém roce se laboratoř např́iklad v rámci kolaborace s Psychological Science Accelerator podílela na výzkumech univerzality morálního rozhodování a účinnosti psychologických intervencí během pandemie, a ve spolupráci s Univerzitou v Cambridge a Kolumbijskou univerzitou zajišt'ovala sběr dat o politické polarizaci v Česku a na Slovensku. Z tuzemských výzkumných organizací PLESS dlouhodobě spolupracuje s Centrem pro behaviorální experimenty (CEBEX), Centrem pro otázky životního prostředí (CŽP) na UK a s nově vytvořeným Centrem laboratorního a experimentálního výzkumu (CEVÝZ) na FPH VŠE.

Kromě vlastních a mezinárodních výzkumů je ale zázemí laboratoře $\mathrm{k}$ dispozici i pro studentské absolventské práce, za předpokladu, že u nich existuje ambice výsledné výstupy publikovat v odborných časopisech. Zároveň laboratoř nabízí studentům možnost dlouhodobějš́ spolupráce, kdy se v roli výzkumných asistentů a asistentek zapojují do procesu návrhu, př́pravy, realizace a vyhodnocení studií. Řada současných a bývalých členů laboratoře dnes úspěšně zhodnocuje zkušenosti získané v PLESSu $\mathrm{v}$ rámci doktorského studia na českých i zahraničních univerzitách; Šimon Kuchařský a František Bartoš na Univerzitě v Amsterdamu, Nikola Frollová a Nicolas Say na FPH VŠE nebo Marek Pour na FSS MUNI.

V dlouhodobém horizontu je cílem laboratoře PLESS nejen umožňovat realizaci co nejširšího spektra psychologických studií, ale především poskytovat podporu pro rozvoj výzkumných dovedností všech se zájmem o vědecký výzkum v psychologii a prríbuzných společensko-vědních oborech.

Pokud se chcete zúčastnit výzkumů v laboratoři PLESS, zaregistrujte se na www.pless.cz/db .

\section{Kontakt}

Pokud máte zájem o spolupráci či další informace, kontaktujte nás na adrese experiment@pless.cz.

Vranka, M. (2021). Experimentální laboratoř PLESS. E-psychologie, 15(4), 101. https://doi.org/10.29364/epsy.429 